\title{
Praktyczne problemy opiniowania przez regionalne izby obrachunkowe możliwości spłaty zobowiązań w jednostkach samorządu terytorialnego
}

\author{
Practical Problems of Giving Opinions by Regional \\ Chambers of Accounting on the Possibility of Repayment \\ of Obligations in Local Government Units
}

\begin{abstract}
Streszczenie. Opinie regionalnych izb obrachunkowych w sprawie możliwości spłaty kredytu, pożyczki lub wykupu papierów wartościowych przez jednostki samorządu terytorialnego wykazują pewne specyficzne cechy w stosunku do pozostałych opinii, odnoszących się do prowadzonej gospodarki finansowej samorządu terytorialnego. Po pierwsze, jako jedyne wydawane są na wniosek organu wykonawczego zainteresowanej jednostki. Po drugie, z racji tego, iż dotyczą problematyki długu, ich treść może być w pewnym stopniu zbieżna, czy też może stanowić „częściowe powielenie” stanowiska zajętego przez regionalną izbę obrachunkową w wydanych już opiniach na etapie planowania budżetowego w j.s.t. Celem niniejszego artykułu jest dokonanie oceny zasadności wydawania tego rodzaju opinii oraz wskazanie relacji pomiędzy zarządzeniami (uchwałami)
\end{abstract}


w sprawie zaciągnięcia kredytu, pożyczki lub wykupu papierów wartościowych a postanowieniami uchwał budżetowych j.s.t.

Słowa kluczowe: dług publiczny jednostek samorządu terytorialnego; regionalne izby obrachunkowe; opinia o możliwości spłaty kredytu, pożyczki lub wykupu papierów wartościowych.

Abstract. Opinions of the regional accounting chambers on the possibility of repayment of the credit, loan or redemption of the securities by local government units have some specific features compared with the other opinions concerning the financial management of the local government. Firstly, they are only issued at the request of the unit that they concerned. Secondly, for the reason they relate to public debt issues, to some extent their content may be similar or "partial reproduction" of the standpoint of the regional chamber of accounting within already issued opinions referring to acts on budgetary planning process in local government units. The purpose of this article is to assess the legitimacy of issuing such opinions and to identify the relationship between the ordinances (resolutions) on the possibility of repayment of the credit, loan or redemption of the securities and provisions of local government budget.

Keywords: public debt of local government units; the regional chambers of accounting; opinion on the possibility of repayment of the credit, loan or redemption of the securities.

\section{Uwagi wprowadzające}

Na podstawie art. 13 pkt 1 ustawy o regionalnych izbach obrachunkowych $^{1}$ oraz art. 91 ust. 2 ustawy o finansach publicznych ${ }^{2}$ regionalne izby obrachunkowe zostały zobowiązane do wydawania opinii o możliwości spłaty planowanych do zaciągnięcia zobowiązań przez jednostki samorządu terytorialnego (j.s.t.) z tytułu kredytu, pożyczki lub wyemitowanych papierów wartościowych. Tego typu opinie, wobec pozostałych odnoszących się do gospodarki finansowej samorządu terytorialnego, wykazują

$1 \quad$ Ustawa z dnia 7 października 1992 r. o regionalnych izbach obrachunkowych (tekst jedn. Dz.U. z 2012 r., poz. 1113 ze zm., dalej: u.r.i.o.).

2 Ustawa z dnia 27 sierpnia 2009 r. o finansach publicznych (tekst jedn. Dz.U. z 2013 r., poz. 885 ze zm., dalej: u.f.p.). 
pewne cechy specyficzne. Po pierwsze, jako jedyne wydawane są na wniosek zainteresowanej jednostki, a w istocie rzeczy na wniosek jej organu wykonawczego. Po drugie, z racji tego, iż odnoszą się do problematyki długu, ich treść może być w pewnym stopniu zbieżna, czy też może stanowić „częściowe powielenie” stanowiska zajętego przez regionalną izbę obrachunkową (RIO) w uprzednio wydanych już opiniach na etapie planowania budżetowego w j.s.t. Do opinii wydawanych na etapie planowania budżetowego zaliczać się będą:

1. przedłożony przez organ wykonawczy projekt uchwały budżetowej (art. 13 pkt 3 u.r.i.o. i art. 238 ust. 3 u.f.p.);

2. przedłożony przez organ wykonawczy projekt uchwały w sprawie wieloletniej prognozy finansowej (art. 13 pkt 12 u.r.i.o. i art. 230 ust. 3 u.f.p.);

3. możliwość sfinansowania deficytu budżetowego przewidzianego w projekcie uchwały budżetowej (art. 246 ust. 1 u.f.p.);

4. możliwość sfinansowania deficytu budżetowego przewidzianego w przyjętej uchwale budżetowej (art. 246 ust. 3 w zw. z ust. 1 u.f.p.);

5. prawidłowość planowanej kwoty długu j.s.t. wynikająca z planowanych lub zaciągniętych zobowiązań (art. 230 ust. 4 u.f.p.).

W tym kontekście pojawia się więc pytanie o zasadność (potrzebę) wydawania opinii o możliwości spłaty kredytu, pożyczki lub wykupu papierów wartościowych, skoro w szerszym zakresie planowane zobowiązania w j.s.t. były już oceniane przez składy orzekające RIO. Ponadto z problemem tym wiąże się kolejna kwestia. Organ wykonawczy wraz wnioskiem o wydanie opinii przedkłada izbie wcześniej wydane zarządzenie (lub uchwałę w przypadku powiatów i województw samorządowych) w sprawie zaciągnięcia zobowiązania z określonego tytułu, w którym niejednokrotnie powiela postanowienia zawarte w uchwale budżetowej, co zostanie szerzej przedstawione w dalszej części artykułu. W efekcie należy postawić kolejne pytanie o znaczenie takich aktów w odniesieniu do uchwały budżetowej.

Powyższe problemy mają przede wszystkim wymiar praktyczny. Występują one na etapie wydawania opinii przez składy orzekające RIO, 
bądź w postępowaniu nadzorczym dotyczącym zarządzeń (uchwał) w sprawie zaciągnięcia zobowiązania przez j.s.t.

Celem niniejszego artykułu będzie dokonanie oceny zasadności formułowania wskazanych kategorii opinii, jak również określenie relacji zachodzących pomiędzy powoływanymi zarządzeniami (uchwałami) a postanowieniami uchwał budżetowych j.s.t.

\section{Tryb oraz zasadność wydawania opinii o możliwości spłaty zobowiązań}

Tak jak już zostało wskazane, wydanie opinii o możliwości spłaty kredytu, pożyczki lub wykupu papierów wartościowych jest uwarunkowane uprzednim skierowaniem wniosku przez organ wykonawczy j.s.t. Tak więc ma on charakter względnie obligatoryjny ${ }^{3}$. Oznacza to, że jednostka, chcąc zaciągnąć zobowiązanie długoterminowe z określonego tytułu (kredytu, pożyczki, emisji papierów wartościowych), musi uzyskać właściwą opinię RIO co do możliwości spłaty takiego zobowiązania. Z kolei opinia ta jest formułowana $\mathrm{z}$ inicjatywy organu wykonawczego, wyrażonej w przedmiotowym wniosku. Dokument ten inicjuje całą procedurę opiniodawczą realizowaną przez wyznaczony skład orzekający izby. Za niedopuszczalne w świetle art. 13 pkt 1 u.r.i.o. należy uznać działanie składu orzekającego polegające na wydaniu opinii bez stosownego wniosku, np. na podstawie informacji wynikających z zarządzenia (uchwały) w sprawie zaciągnięcia określonego rodzaju zobowiązania, które jest przedmiotem postępowania nadzorczego kolegium izby.

Na podstawie art. 91 ust. 2 u.f.p. stwierdzić należy, że opinia powinna wyrażać pozytywne lub negatywne stanowisko RIO w sprawie „możliwości spłaty” przez j.s.t. planowanego do zaciągnięcia zobowiązania, przy czym znaczenie tego sformułowania, jak pokazuje praktyka, jest

3 Zob. również J.M. Salachna, Istota i zakres oraz funkcje działalności opiniodawczej regionalnych izb obrachunkowych komentarz do art. 13 u.r.i.o., [w:] M. Stec (red.), Regionalne izby obrachunkowe. Charakterystyka ustrojowa i komentarz do ustawy, Warszawa 2010, s. 163 i 417; R. Trykozko, Ustawa o finansach publicznych. Komentarz dla jednostek samorzq̨du terytorialnego, Warszawa 2010, s. 187. 
dosyć szerokie. Ocena składu orzekającego powinna być wszechstronna, tzn. z jednej strony powinna dotyczyć finansowych zdolności jednostki wywiązania się ze zobowiązania $\mathrm{w}$ dacie jego zapadalności, przy uwzględnieniu regulacji ograniczających dług publiczny, a głównie indywidualnego wskaźnika spłaty zobowiązań określonego w art. 243 u.f.p. W tym kontekście skład orzekający bierze pod uwagę bieżącą i prognozowaną sytuację finansową j.s.t., przy czym zasadniczym kryterium oceny powinna być legalność ${ }^{4}$. Z drugiej strony przedmiotem analizy powinno być również spełnienie formalno-prawnych warunków, w szczególności zachowanie ogólnego limitu zobowiązań oraz wynikających z niego cząstkowych limitów przyporządkowanych poszczególnym rodzajom zobowiązań, które zostały ujęte w uchwale budżetowej (zob. art. 212 ust. 1 pkt 6 u.f.p.), a także posiadanie upoważnień przez organ wykonawczy do podjęcia zobowiązania, którego dotyczy wniosek ${ }^{5}$.

Biorąc pod uwagę wszystkie elementy podlegające ocenie, pojawia się wątpliwość o merytoryczną zasadność takiej opinii ${ }^{6}$, skoro już wcześniej RIO na etapie planowania budżetowego j.s.t. wyraziła swoje stanowisko dotyczące rozmiarów i struktury jej zadłużenia, w szczególności rodzajów zobowiązań, które mają być zaciągnięte w danym roku budżetowym, ich limitów czy kształtowania się wskaźnika z art. 243 u.f.p. Stanowisko to zostało zawarte w treści opinii, m.in. na temat projektu wieloletniej prognozy finansowej (WPF) oraz w opinii sformułowanej już po uchwaleniu WPF i budżetu jednostki - w sprawie prawidłowości planowanej kwoty długu i możliwości sfinansowania deficytu. Tak więc opinia o możliwości spłaty określonego kredytu, pożyczki czy wykupu wyemitowanych papierów wartościowych jest niejako „pochłaniana” przez powoływane opinie i w tym kontekście może wydawać się bezprzedmiotowa. Natomiast za jej pozostawieniem w obiegu prawnym przemawia fakt,

\footnotetext{
J.M. Salachna, Istota i zakres..., s. 167.

5 Szerzej o treści opinii zob. M. Tyniewicki, Ogólne zasady zaciqgania zobowiq̨zań przez inne niż Skarb Państwa jednostki sektora finansów publicznych, [w:] E. Ruśkowski, J.M. Salachna (red.), Finanse publiczne 2014. Komentarz praktyczny (z suplementem elektronicznym), Gdańsk 2014, s. 425.

$6 \quad$ J.M. Salachna, komentarz do art. 13 u.r.i.o., [w:] M. Stec (red.), Regionalne izby obrachunkowe. Charakterystyka ustrojowa i komentarz do ustawy, Warszawa 2010, s. 418.
} 
że skład orzekający powinien dokonać oceny także bieżącej sytuacji finansowej jednostki, która nie mogła być przedmiotem analizy na etapie planowania oraz uchwalania budżetu i WPF. Tym bardziej że w przeważającej części jednostki zwracają się z wnioskami o wydanie opinii w drugiej połowie roku budżetowego, a nawet pod jego koniec, tj. w listopadzie lub w grudniu. Co więcej, niejednokrotnie tego typu opinie są wymagane przez wierzycieli przekazujących środki dłużne, a już regułą jest to w przypadku pożyczek/kredytów na tzw. wyprzedzające finansowanie działań finansowanych ze środków pochodzących z Unii Europejskiej (art. 89 ust. 1 pkt 4 u.f.p.). Sytuacje takie mogą stwarzać iluzję, że opinia RIO powinna mieć charakter wszechstronnej oceny kredytowej j.s.t., która np. określi zdolność płatniczą jednostki, czy też jej rating kredytowy ${ }^{7}$. Stanowisko takie jest błędne chociażby z tego powodu, iż j.s.t. nie należy utożsamiać z typowym podmiotem gospodarczym ubiegającym się o finansowanie zwrotne, a formułowanie opinii - co autor już podkreślił - powinno opierać się przede wszystkim na kryterium legalności.

Zaznaczyć należy, że na podstawie art. 3 ust. 4 ustawy z dnia 29

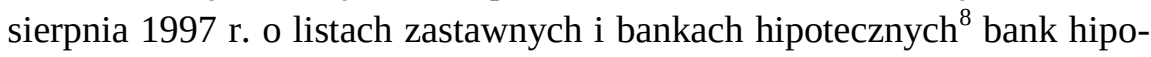
teczny, udzielając j.s.t. kredytu lub nabywając od niej papiery wartościowe, jest obowiązany uzyskać opinię RIO o możliwości spłaty kredytu lub wykupu papierów wartościowych.

\section{Zarządzenie (uchwała) organu wykonawczego o zaciągnięciu zobowiązania a postanowienia uchwały budżetowej}

Skierowanie do RIO wniosku o wydanie opinii poprzedzone jest wydaniem zarządzenia wójta, burmistrza, prezydenta bądź uchwałą zarządu powiatu lub zarządu województwa w sprawie zaciągnięcia określonego

J.M. Salachna, komentarz do art. 13 u.r.i.o., [w:] M. Stec (red.), Regionalne izby obrachunkowe. Charakterystyka ustrojowa i komentarz do ustawy, Warszawa 2010, s. 419. Tekst jedn. Dz.U. z 2003 r., Nr 99, poz. 919 ze zm. 
zobowiązania. Akty są objęte postępowaniem nadzorczym kolegium izby. Ich materia obejmuje następujące elementy:

1. rodzaj zobowiązania, które jednostka planuje zaciągnąć, z jednoczesną konkretyzacją przeznaczenia uzyskanych środków, przy czym musi być ono zbieżne z celami, dla których jednostki kreują swoje zadłużenie (zob. art. art. 89 ust. 1 pkt. 1, 3 i 4 u.f.p.) i które muszą mieć odzwierciedlenie w uchwale budżetowej;

2. nominalnie określona kwota zobowiązania, która powinna mieścić się w limicie danej kategorii zobowiązania (kredytu, pożyczki, emisji papierów wartościowych); limit ten wynika z uchwały budżetowej;

3. planowane źródło i termin spłaty zobowiązania, przy czym termin ten będzie wykraczał poza dany rok budżetowy, ponieważ w zasadzie tylko zobowiązania długoterminowe podlegają opiniowaniu w świetle art. 91 ust. 2 u.f.p.

Wynika więc z tego, że postanowienia zawarte w zarządzeniach (uchwałach) w sprawie zaciągnięcia zobowiązania stanowią konkretyzację treści uchwały budżetowej, co oznacza, że muszą być wydawane w ramach dyspozycji przepisów tej uchwały. Natomiast żaden z aktów prawnych dotyczących szeroko pojętej gospodarki finansowej j.s.t. nie zawiera jednoznacznego przepisu będącego bezpośrednią podstawą dla kreowania takich zarządzeń (uchwał). Najczęściej organy wykonawcze w procesie ich stanowienia jako podstawę prawną wskazują m.in.: art. 89 ust. 1, art. 262 ust. 1 u.f.p., przepisy samorządowych ustaw ustrojowych - np. art. 30, art. 58, art. 60 ustawy o samorządnie gminnym ${ }^{9}$ oraz przepisy uchwał budżetowych zawierających limity zobowiązań i fakultatywnie upoważnienia dla organów wykonawczych do ich zaciągania. Pomimo tego stanu rzeczy, z praktycznego punktu widzenia zarządzenia (uchwały) tego rodzaju są pomocne dla składów orzekających izb, szczególnie przy formalno-prawnej ocenie wniosku, chociaż powinna ona być dokonywana przede wszystkim w oparciu o obowiązującą uchwałę budżetową j.s.t.

Na szczególną uwagę zasługuje nierzadko występująca praktyka postępowania organów wykonawczych j.s.t. podczas wydawania czy to za-

9 Ustawa z dnia 8 marca 1990 r. o samorządzie gminnym (tekst jedn. Dz.U. z 2013 r., poz. 594 ze zm.). 
rządzeń (uchwał) o zaciągnięciu zobowiązania, czy to kierowania wniosków o wydanie opinii, polegająca na określaniu w tych dokumentach górnej granicy zobowiązania, co często jest po prostu powieleniem przepisu uchwały budżetowej, ustanawiającego limit dla takiego zobowiązania. Wydaje się, że działanie takie jest niewłaściwe, mając na uwadze dyspozycję art. 91 ust. 2 u.f.p. Przepis ten stanowi, że „w przypadku ubiegania się (...) o kredyt lub pożyczkę (...), a także w przypadku zamiaru emisji (...) papierów wartościowych (...), zarząd (...) jest obowiązany uzyskać opinię regionalnej izby obrachunkowej”. Chodzi więc o konkretny kredyt, pożyczkę lub emisję papierów wartościowych, których podjęcie powinno być podyktowane realnymi potrzebami j.s.t. Nie można bowiem kreować czy generować długu jednostki bez zaistnienia okoliczności uzasadniających zaciągnięcie takiego długu, określonych w art. 89 ust. 1 u.f.p. Bardzo często jednostki swoje postępowanie uzasadniają chęcią uzyskania „z góry” opinii na cały limit zobowiązania, co tym samym spowoduje, że zbędne będzie występowanie z kolejnymi wnioskami, a raz udzielona opinia zostanie wykorzystana wielokrotnie. Przyjmując takie stanowisko, z którym autor się nie zgadza, można dojść do wniosku, iż opinie określone w art. 91 ust. 2 u.f.p są całkowicie zbędne z merytorycznego punktu widzenia. Ponieważ już na etapie projektowania budżetu i WPF oraz po ich uchwaleniu RIO wydała opinie, w których odniosła się do problemu zadłużenia j.s.t., w tym także do planowanych zobowiązań i ich limitów (np. w opinii w sprawie prawidłowości planowanej kwoty długu i możliwości sfinansowania deficytu). Jednak, co zauważył już autor, opinie formułowane na etapie planowania nie uwzględniają bieżącej sytuacji finansowej samorządu, co jest o niezmiernie istotne w przypadku zbyt optymistycznego oszacowania wielkości budżetowych na początku roku budżetowego, które pośrednio lub bezpośrednio wpływają na stan zobowiązań j.s.t.

\section{Wnioski}

Na podstawie analizy problematyki podjętej w niniejszym artykule można przedstawić następujące wnioski końcowe: 
1. Biorąc pod uwagę wszystkie elementy podlegające ocenie przy wydawaniu opinii o możliwości spłaty kredytu, pożyczki lub wykupu papierów wartościowych przez j.s.t., pojawia się wątpliwość o merytoryczną zasadność takiej opinii, skoro wcześniej RIO na etapie planowania budżetowego $\mathrm{w}$ jednostce wyraziła swoje stanowisko dotyczące rozmiarów i struktury jej zadłużenia. Za pozostawieniem w obiegu prawnym tego typu opinii przemawia jednak fakt, że składy orzekające izb wyrażając swoje stanowisko, powinny oceniać także bieżącą sytuację finansową jednostki, która nie mogła być przedmiotem analizy na etapie planowania oraz uchwalania budżetu i WPF. Ponadto niejednokrotnie opinie te są wymagane przez podmioty przekazujące środki dłużne, np. w przypadku pożyczek/kredytów na tzw. wyprzedzające finansowanie określonych w art. 89 ust. 1 pkt 4 u.f.p.

2. Skierowanie do RIO wniosku o wydanie opinii poprzedzone jest zarządzeniem wójta, burmistrza, prezydenta, bądź uchwałą zarządu powiatu lub zarządu województwa, w sprawie zaciągnięcia określonego zobowiązania. Postanowienia zawarte $\mathrm{w}$ aktach tego typu stanowią konkretyzację treści uchwały budżetowej w zakresie podejmowanych przez j.s.t. zobowiązań, a więc muszą być wydawane w ramach dyspozycji przepisów tej uchwały.

3. Nierzadko występującą praktyką postępowania organów wykonawczych j.s.t. podczas wydawania czy to zarządzeń (uchwał) o zaciągnięciu zobowiązania, czy to kierowania wniosków o wydanie opinii, jest określanie w tych dokumentach górnej granicy zobowiązania, co często stanowi powtórzenie przepisu uchwały budżetowej, ustanawiającego limit dla takiego zobowiązania. Wydaje się, że działanie takie jest niewłaściwe, mając na uwadze dyspozycję art. 91 ust. 2 u.f.p. Organ wykonawczy powinien wskazać konkretną kwotę kredytu, pożyczki lub emisji papierów wartościowych, których podjęcie powinno być podyktowane realnymi potrzebami j.s.t. Nie można bowiem kreować czy generować długu jednostki bez zaistnienia okoliczności uzasadniających jego zaciągnięcie, a które zostały określone w art. 89 ust. 1 u.f.p. 
Marcin Tyniewicki

\section{Bibliografia:}

Trykozko R., Ustawa o finansach publicznych. Komentarz dla jednostek samorzqdu terytorialnego, Taxpress, Warszawa 2010.

Salachna J.M., Istota i zakres oraz funkcje działalności opiniodawczej regionalnych izb obrachunkowych, [w:] M. Stec (red.), Regionalne izby obrachunkowe. Charakterystyka ustrojowa i komentarz do ustawy, Wolters Kluwer, Warszawa 2010.

Tyniewicki M., Ogólne zasady zaciągania zobowiq̨zań przez inne niż Skarb Państwa jednostki sektora finansów publicznych, [w:] E. Ruśkowski, J.M. Salachna (red.), Finanse publiczne 2014. Komentarz praktyczny (z suplementem elektronicznym), ODDK, Gdańsk 2014. 